\title{
Correction: Systematic review and meta-analysis of prolactin and iron deficiency in peripartum cardiomyopathy
}

Cherubin S, Peoples T, Gillard J, et al. Systematic review and meta-analysis of prolactin and iron deficiency in peripartum cardiomyopathy. Open Heart 2020;7:e001430. doi:10.1136/openhrt-2020-001430

The contributors statement has been amended to remove MY, and to include MN as a contributor to the conception and design of the work.

Open access This is an open access article distributed in accordance with the Creative Commons Attribution 4.0 Unported (CC BY 4.0) license, which permits others to copy, redistribute, remix, transform and build upon this work for any purpose, provided the original work is properly cited, a link to the licence is given, and indication of whether changes were made. See: https:// creativecommons.org/licenses/by/4.0/.

C Author(s) (or their employer(s)) 2020. Re-use permitted under CC BY. Published by BMJ.

Open Heart 2020;7:e001430corr1. doi:10.1136/openhrt-2020-001430corr1

A) Check for updates 